\title{
Determination of 2,6-diaminopimelic acid in bacteria, ruminal and duodenal digesta using HPLC with fluorescence or UV detection
}

\author{
M. Czauderna and J. Kowalczyk \\ The Kielanowski Institute of Animal Physiology and Nutrition, \\ Polish Academy of Sciences \\ 05-110 Jablonna, Poland
}

(Received 21 December 1998; accepted 19 March 1999)

\begin{abstract}
A high-performance liquid chromatography method with pre-column derivatization was tested and used in the analysis of partially separated 2,6-diaminopimelic acid (DAPA) in rumen bacteria, duodenal digesta and feeds incubated in vitro with rumen fluid. The samples of analyzed materials were hydrolyzed with $6 \mathrm{M} \mathrm{HCl}$ for $20 \mathrm{~h}$ at $104 \pm 2^{\circ} \mathrm{C}$. DAPA was determined after pre-column derivatization with $o$-phthaldialdehyde (OPA) in the presence ethanethiol (ESH). Separation of converted DAPA was carried out using a reversed-phase column (Nova-Pak C-18, $4 \mu \mathrm{m}, 250 \times 4.6 \mathrm{~mm}$ I.D., Waters) by a binary gradient program and fluorescence or UV detection. The converted DAPA (as two peaks) was fluorescently monitored at an excitation wavelength of $229 \mathrm{~nm}$, with $470 \mathrm{~nm}$ cutoff-filter (the retention times: $33.83 \pm 0.16$ and $34.43 \pm 0.16 \mathrm{~min}$ ), while the $U V$ detector was set at 229 $\mathrm{nm}$ (retention times: $33.75 \pm 0.16$ and $34.36 \pm 0.16 \mathrm{~min}$ ). The DAPA peaks were completely resolved from interfering species in about $41 \mathrm{~min}$. After $41 \mathrm{~min}$, the column was re-equilibrated and cleaned, depending on the type of analyzed sample, for 9-14 min. The average analytical recoveries were $98.4 \pm 3.1 \%$ with fluorescence detection and $96.7 \pm 4.0 \%$ with UV detection for total DAPA. The low within and between run coefficients of variations, high recoveries and low detection $(2.05 \mathrm{nmol} / \mathrm{ml})$ and quantification $(6.78 \mathrm{nmol} / \mathrm{ml})$ limits, point to satisfactory precision, reproducibility, accuracy and sensitivity of the proposed method. The use of fluorescence detection and the sum of DAPA peaks give the method high precision and accuracy. The presented method enabled partial separation of DAPA stereoisomers, therefore this new HPLC procedure can also be used for investigations of DAPA metabolism within the rumen microbial ecosystem.
\end{abstract}

KEY WORDS: 2,6-diaminopimelic acid, indirect marker, determination, HPLC 


\section{INTRODUCTION}

The amino acid 2,6-diaminopimelic acid (DAPA) is a unique component of bacterial cell walls (Hoshino et al., 1990; Mohau et al., 1992), thus its use as an indirect and specific indicator for the measurement of bacterial mass content in such biological materials as feeds or digestive tract contents in ruminants (Masson et al., 1991; Robinson et al., 1996). The traditional method used to quantitate DAPA is ion-exchange chromatography (IEC) followed by the ninhydryn reaction (Hutton et al., 1971; Mzik et al., 1978; Edols, 1985). This method is reliable and the resolution of the amino acids is reasonable, but the analysis time is long and has a rather limited delectability (ca $150 \mathrm{pmol}$ ). An expensive amino acid analyzer is required (Benson, 1975), and high levels of methionine in analyzed samples can interfere with the determination. The alternative method proposed by Czerkawski (1974) using charcoal and anionic resin columns is less expensive but is labour intensive and sensitive to interference from proline.

The use of gradient high-performance liquid chromatography (HPLC) for the quantitative analysis of DAPA in biological materials has become widely popular in recent years due to its sensitivity, accuracy and reliability (Rattenbury, 1981; Lindroth et al., 1985; Nagasawa et al., 1993; Sarwar et al., 1993; El-Waziry et al., 1996). Furthermore, the use of reversed-phase HPLC with pre-column derivatization using $o$-phthaldialdehyde (OPA) and 2-mercaptoethanol $(\mathrm{E}(\mathrm{OH}) \mathrm{SH})$ for analysis of DAPA is becoming established as a more sensitive, reliable and cheaper alternative to commercial amino acid analyzers (Rattenbury, 1981; Webster et al., 1990; Sawar et al., 1993; Puchała et al., 1992; Czauderna et al., 1998). Webster et al. (1990) reported a method for the determination of partly separated stereoisomers of DAPA by HPLC, however, it requires costly purification of biological samples and individual sample running time is high. Earlier studies have demonstrated that analyses of DAPA and other primary amino acids can also be performed successfully using OPA in the presence of ethanethiol (ESH) (Dennis et al., 1979; Krishnamurti et al., 1984; Lindroth et al., 1985). Promising results have been obtained on the separation of DAPA, cystine or cysteine as their OPA/ESH derivatives (Czauderna et al., 1998, 1999). In the recent method of DAPA determination by reversed-phase HPLC described by Czauderna et al. (1999), UV detection at $340 \mathrm{~nm}$ was used. UV detection is an appropriate method for direct determination of a relatively high level (nmole range) of DAPA in biological samples. The sensitivity of fluorescence detection is generally several times higher than of UV detection set at $340 \mathrm{~nm}$, and fluorescence detection exhibits a broad linear range for most OPA-derivatized primary amino acids (Davies et al., 1992). Thus, we applied this method of detection in the monitoring of DAPA. Moreover, thanks to the use of the sensitive fluorescence detection, the problem of loading highly concentrated samples on the column can be avoided. 
The aim of this study was to develop the gradient conditions for HPLC and to improve fluorescence and UV detection.

\section{MATERIAL AND METHODS}

\section{Reagents}

Ethanethiol (ESH) was obtained from Aldrich (Germany), while $o$-phthaldialdehyde (OPA) and DL 2,6-diaminopimelic acid (a mixture of LL, DD and meso stereoisomers) from Sigma (St. Louis, MO, USA). HPLC-grade acetonitrile was purchased from Merck (Darmstadt, Germany). Methanol and other chemicals were of analytical reagent grade (POCH, Gliwice, Poland). Water used for the preparation of eluent buffers and for dissolving DAPA standards or chemical reagents was prepared using an Elix ${ }^{\mathrm{TM}}$ water purification system (Millipore, Toronto, Canada). The mobile phase (solvents $A$ and $B$ ) was filtered through a $0.45 \mathrm{~mm}$ membrane filter (Millipore). Solvents A and B were degassed for 5-7 min in vacuum with ultrasonication prior to use.

\section{Chromatographic equipment}

The instrument consisted of a Waters 625LC system that includes a controller for gradient elution and two Waters Model 501 pumps. The apparatus is coupled to a Waters 712 WISP autosampler, a Waters 474 fluorescence detector, an absorbance detector (Waters Model 486) and a computer data handling system (all equipment from Waters, Millipore, MA, USA). The OPA derivatives were monitored using the fluorescence detector (excitation monochromator set at $229 \mathrm{~nm}$, emission measured with a $470 \mathrm{~nm}$ cut-off filter) or the UV detector which was operated at $229 \mathrm{~nm}$ with an attenuation of 0.01 a.u.f.s. (absorbance unit full scale). Development of the analytical method, collection and data integration were performed using Millennium 2001 software and an Optimus Pentium 5P60 computer.

The analytical column used was a Nova-Pak C-18 column $(4 \mu \mathrm{m}, 250 \times 4.6 \mathrm{~mm}$ I.D., Waters) in conjunction with a guard column (Waters) of $10 \times 6 \mathrm{~mm}$ I.D. containing reversed-phase $\mathrm{C}-18(30-40 \mu \mathrm{m})$ pellicular packing material.

\section{Analytical solvents and gradient composition}

Two HPLC grade solvents were used in this study. Solvent A was acetonitrilebuffer $(4: 23 \mathrm{v} / \mathrm{v})$. The buffer for solvent $A$ was prepared from $0.02 \mathrm{M} \mathrm{Na}_{2} \mathrm{HPO}_{4}$ adjusted to $\mathrm{pH} 6.4$ with $\sim 50 \%$ phosphoric acid. Solvent $\mathrm{B}$ was acetonitrile-methanol-water $(30: 30: 40, v / v)$. 
For analysis of DAPA in standards and biological samples, a binary gradient curvilinear Waters program was used. When solvent A rose from 0 to $100 \%$, the system pressure increased from $23.26 \pm 0.55$ to $28.28 \pm 0.56 \mathrm{MPa}$. The gradient composition is shown in Table 1. The run time of the analysis was $41 \mathrm{~min}$. After $41 \mathrm{~min}$, the column was re-equilibrated and cleaned, depending on the type of sample, for 9-14 $\mathrm{min}$ in $100 \%$ solvent $\mathrm{A}$ at a flow-rate of $1.7 \mathrm{ml} / \mathrm{min}$. All separations were performed at a column temperature of $25^{\circ} \mathrm{C}$ in an ambient temperature of $18-20^{\circ} \mathrm{C}$. The retention times and the elution order are variable depending on column and ambient temperatures.

\section{Preparation of the borate buffer}

Boric acid, $2.473 \mathrm{~g}$, was dissolved in $80 \mathrm{ml}$ of reagent grade water and the $\mathrm{pH}$ adjusted to $9.8-9.9$ with $4 \mathrm{M} \mathrm{KOH}$. The resulting solution was filtered and diluted to a total volume of $100 \mathrm{ml}$ to make $0.4 \mathrm{M}$ borate buffer.

\section{Preparation of derivatizing solution}

Seventy-five milligrams of OPA were dissolved in $4.5 \mathrm{ml}$ of methanol and $0.5 \mathrm{ml}$ borate buffer. Seventy microliters of ESH were added and the resulting solution was mixed. It is recommended to protect the derivatizing solution from light and to store refrigerated $\left(-28^{\circ} \mathrm{C}\right)$ when not in use. The reagent strength was maintained by addition of $10 \mu 1$ of ESH every 2 days.

\section{Preparation and hydrolysis of samples}

Samples of rumen bacteria (Lachnospira multiparus 685), feed incubated with rumen fluid, or duodenal digesta were frozen, lyophilized and the obtained materials (about $500 \mathrm{mg}$ ) hydrolyzed with $50 \mathrm{ml}$ of $6 \mathrm{M} \mathrm{HCl}$ at $104 \pm 2^{\circ} \mathrm{C}$ for $20 \mathrm{~h}$ in sealed tubes. After cooling the hydrolysate was filtered through filter paper and washed two times with deionized water. Hydrochloric acid was removed from the filtrate in a vacuum rotary evaporator. Twenty milliliters of deionized water were added to the residue and then evaporated to dryness again in vacuum to remove residues of $\mathrm{HCl}$. The hydrolyzates were stored at $-20^{\circ} \mathrm{C}$ until analyzed. The residue was redissolved in $5 \mathrm{ml}$ of the borate buffer $(\mathrm{pH} \mathrm{9.8-9.9)}$ and then used for the derivatization as below.

\section{Derivatization procedure}

To an autosampler vial were added $20 \mu \mathrm{l}$ of redissolved sample, $400 \mu \mathrm{l}$ of $\mathrm{OPA} / \mathrm{ESH}$ derivatizing solution and $10 \mu \mathrm{l}$ of $1 \mathrm{M} \mathrm{NaOH}$. The contents were mixed and 
reacted for $4 \mathrm{~min}$ at room temperature. All mixtures were protected from light. At the end of the 4 min period, 5-20 $\mu$ lof the derivatized sample were injected onto the column. The derivatizing procedure for standards was the same as for biological samples. Peaks were identified on the basis of retention time of processed standards injected separately and by adding standard solution to biological samples.

The limit of detection was calculated as a signal-to-noise ratio of 3 , while the limit of quantification is defined as 10 times the noise level (Gratzfeld-Husgen et al., 1994).

\section{RESULTS AND DISCUSSION}

Fluorescence and short wavelength UV detection were used in this study. Generally, the sensitivity of fluorescence detection is about eight times higher than that of UV detection at $340 \mathrm{~nm}$ (Puchała et al., 1992). To avoid this poor detection, the UV detector was set at short wavelengths. Studies on the fluorescent emission of $o$-phthaldialdehede/ethanethiol derivatives of amino acids showed that the highest emission was obtained by excitation at $229 \mathrm{~nm}$ (Hill et al., 1979). Therefore, in this study UV detection at $229 \mathrm{~nm}$ was used. It can also be noted that excitation in the $330-340 \mathrm{~nm}$ band produced one-sixth of the fluorescent emission signal as compared to excitation at $229 \mathrm{~nm}$ (Hill et. al., 1979). The fluorescence detector was therefore set at an excitation wavelength of $229 \mathrm{~nm}$.

The main analytical problem in the present work was obtaining suitable separation of DAPA peaks from background interference and interfering compounds of biological samples. In biological samples many compounds, including DAPA, are poorly retained on $\mathrm{C}-18$ columns or have high absorbance at short wavelength. Therefore, to avoid problems due to overlapping peaks, DAPA was converted, prior to HPLC separation, to highly fluorescent thioalkyl-substituted isoindoles. Attempts were also made to combine this pre-column derivatization procedure with a chromatographic run involving manipulation of retention behaviour by modifying gradient conditions and the composition of the mobile phases. As can be seen from the representative chromatograms in Figures 1 and 2, the proposed HPLC procedure with fluorescence and UV detection allows satisfactory separation of DAPA stereoisomers from unidentified peaks and background interference. Moreover, the composition of the mobile phases and the gradient elution system developed in this work significantly reduced the column pressure in the HPLC system, allowing the more rapid elution of all DAPA stereoisomers in comparison with the DAPA elution by the earlier HPLC method (Czauderna et al., 1999). Figures 1 and 2 illustrate the application of the procedure to the analysis of rumen bacteria (A), duodenal digesta (B), feeds incubated in vitro with rumen fluid (C), and a DAPA standard 

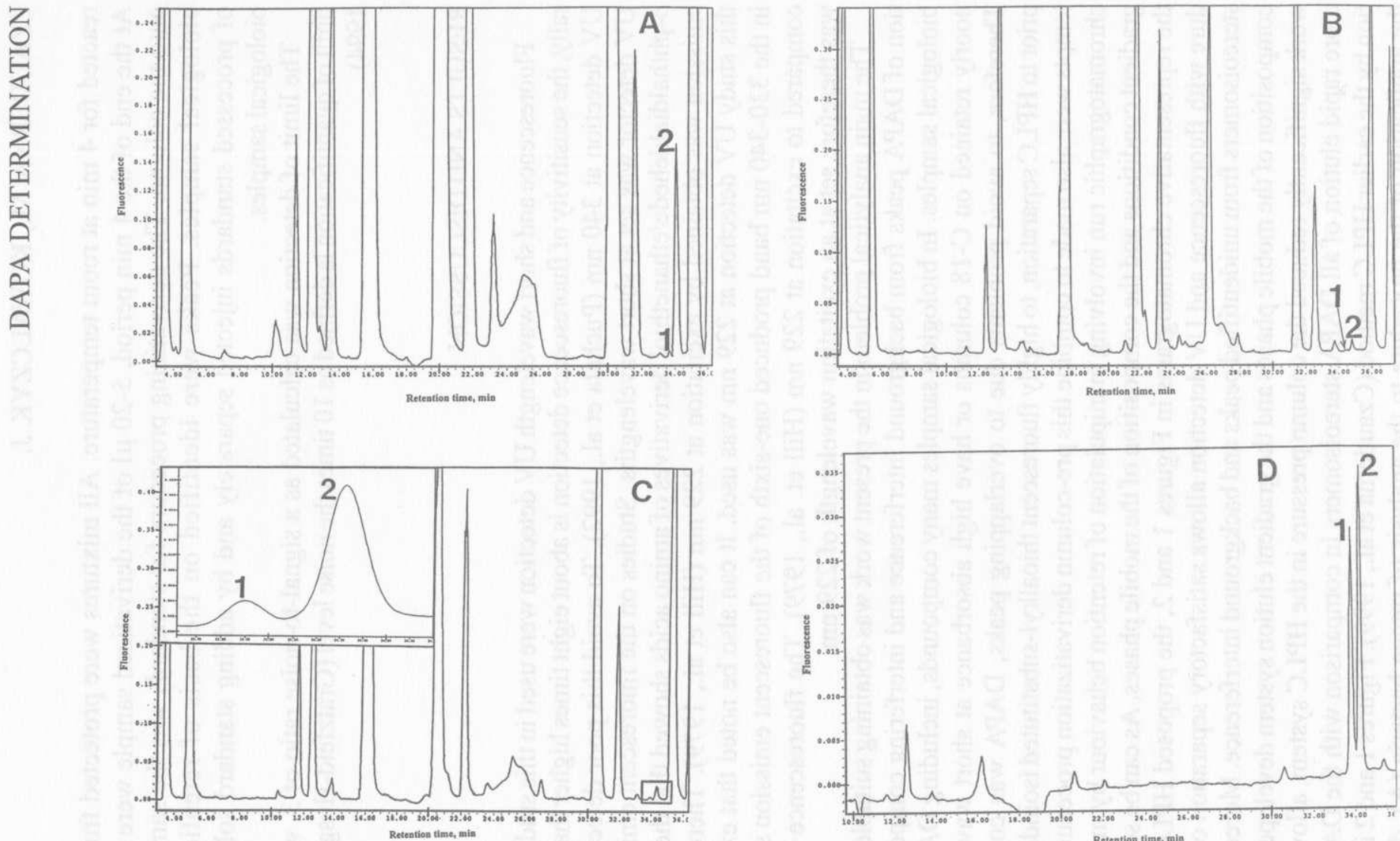

Figure 1. Chromatograms for processed samples by new HPLC metod with the fluorescence detection (an excitation wavelength of $229 \mathrm{~nm}$ and emission cut-off filter of $470 \mathrm{~nm})$. Injections volumes were $20 \mu \mathrm{l}$. A - the bacterial sample $(1.51 \mathrm{mg}$ of lyophilized bacterial hydrolyzates; a volume of a reaction mixture: $632 \mu \mathrm{l}$ ). B - duodenal digesta. $\mathrm{C}$ - the feed in vitro incubated in the rumen fluid. D - a processed DAPA standard 

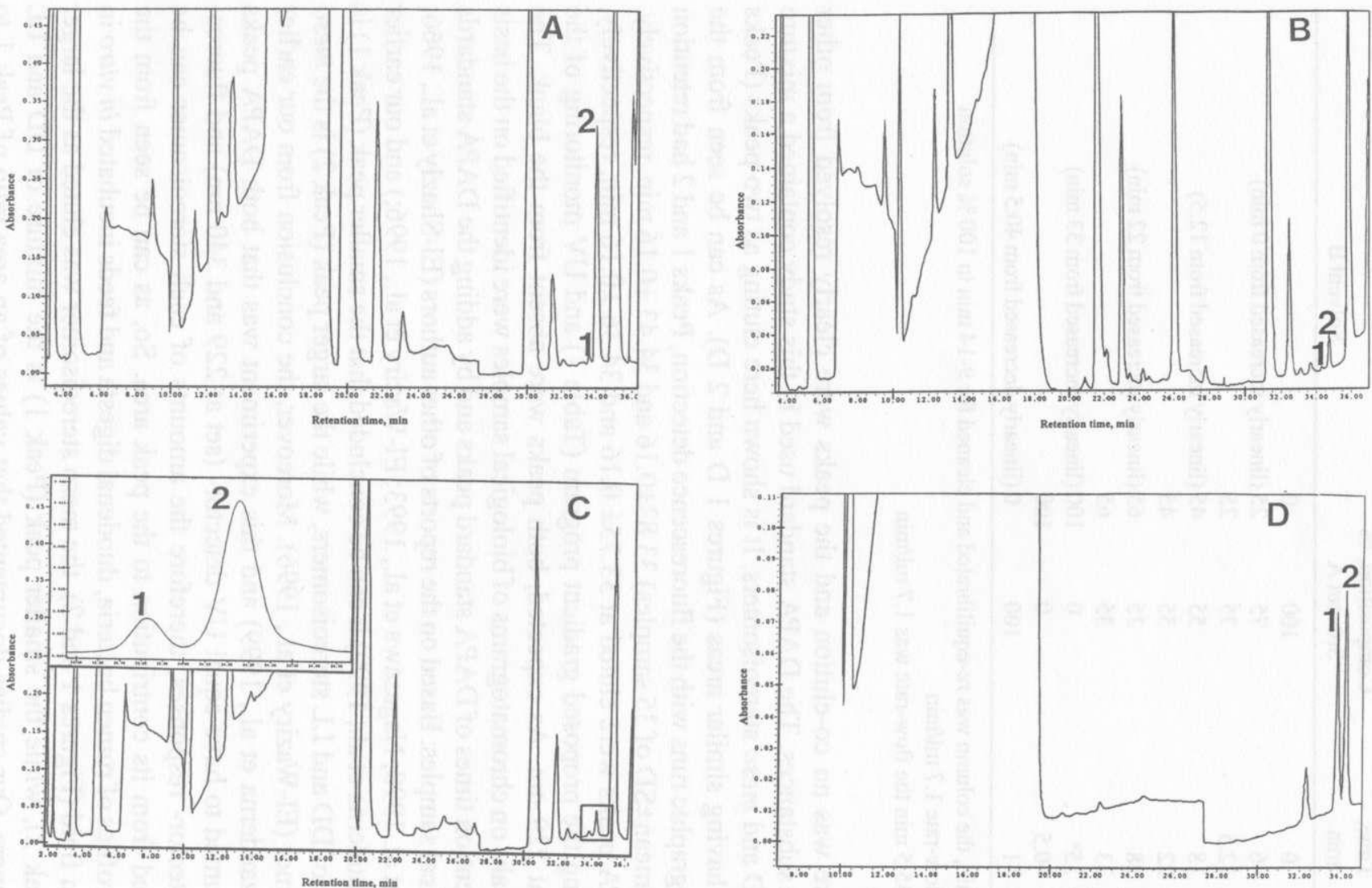

Figure 2. Chromatograms for processed samples by new HPLC method with the UV detection at $229 \mathrm{~nm}$. Injections volumes were $20 \mu \mathrm{l}$. A - the bacterial sample ( $1.51 \mathrm{mg}$ of lyophilised bacterial hydrolizate; a volume of a reaction mixture: $632 \mu \mathrm{l})$. B - duodenal digesta. $\mathrm{C}$ - the feed in vitro incubated in the rumen fluid. D - a processed DAPA standard 
TABLE 1

Gradient composition (the flow rate $-1.5 \mathrm{ml} / \mathrm{min}^{\mathrm{s}}$ )

\begin{tabular}{ccc}
$\begin{array}{c}\text { Time, } \\
\text { min }\end{array}$ & $\begin{array}{c}\text { Composition, } \% \\
\text { Solvent A }\end{array}$ & Solvent B \\
\hline 0 & 100 & 0 \\
6 & 75 & 25 (linearly increased from 0 min) \\
12.5 & 75 & 25 \\
18 & 55 & 45 (linearly increased from 12.5$)$ \\
22 & 55 & 45 \\
28 & 35 & 65 (linearly increased from $22 \mathrm{~min})$ \\
33 & 35 & 65 \\
$35^{\mathrm{b}}$ & 0 & 100 (linearly increased from $33 \mathrm{~min})$ \\
40.5 & 0 & 100 \\
41 & 100 & 0 (linearly decreased from $40.5 \mathrm{~min})$ \\
\hline
\end{tabular}

a after $41 \mathrm{~min}$, the column was re-equilibrated and cleaned for $9-14 \mathrm{~min}$ in $100 \%$ solution A at the flow-rate $1.7 \mathrm{ml} / \mathrm{min}$

b after the $35.5 \mathrm{~min}$ the flow-rate was $1.7 \mathrm{ml} / \mathrm{min}$

(D). There was no co-elution and the peaks were clearly resolved from other unknown substances. The DAPA standard used in this study contained a mixture of LL, DD and meso stereoisomers. It is shown here eluting as two peaks (Peaks 1 and 2) having similar areas (Figures $1 \mathrm{D}$ and $2 \mathrm{D}$ ). As can be seen from the chromatographic runs with the fluorescence detection, Peaks 1 and 2 had retention times of (mean \pm SD of 35 samples) $33.83 \pm 0.16$ and $34.43 \pm 0.16$ min, respectively. The DAPA peaks were eluted at $33.75 \pm 0.16$ and $34.36 \pm 0.16 \mathrm{~min}$, respectively, when using the proposed gradient program (Table 1) and UV monitoring of the effluent at $229 \mathrm{~nm}$. As expected, both peaks were absent from the blank. The DAPA peaks on chromatograms of biological samples were identified on the basis of the retention times of DAPA standard peaks and by adding the DAPA standards to biological samples. Based on the reports of other authors (El-Shazly et al., 1966; Webster et al. 1990; Nagasawa et al., 1993; El-Waziry et al., 1996;) and our earlier work (Czauderna et al., 1999) it can be concluded that the smaller peak (Peak 1) is a mixture of DD and LL stereoisomers, while the larger peak (Peak 2) is the meso stereoisomer (El-Waziry et al., 1996). Moreover, the conclusion from our earlier study (Czauderna et al., 1999) and this experiment was that both DAPA peaks were assumed to have equal UV detector- (set at 229 and $340 \mathrm{~nm}$ ) and fluorescence detector- responses, therefore the amounts of each stereoisomer can be determined from its contribution to the peak area. So, as can be seen from the elution profiles of rumen bacteria, duodenal digesta and feeds incubated in vitro in the rumen fluid (Figures 1 and 2), the meso stereoisomer was eluted as the larger peak (Peak 2), while the smaller peak (Peak 1) is the mixture of DD and LL stereoisomers. Our studies documented that values of an area ratio of Peak 1 to 
TABLE 2

The ratios of Peak 1 to Peak 2 as depended upon used detector and type of processed biological samples

\begin{tabular}{lll}
\hline \multicolumn{1}{c}{ Sample } & \multicolumn{1}{c}{$\begin{array}{c}\text { Fluorescence detection } \\
\text { ratio }\end{array}$} & \multicolumn{1}{c}{$\begin{array}{c}\text { UV detection } \\
\text { ratio }\end{array}$} \\
\hline Rumen bacteria & $0.0185(229 / 470 \mathrm{~nm})^{\mathrm{a}}$ & $\begin{array}{l}0.0240(229 \mathrm{~nm})^{\mathrm{b}} \\
0.0257(340 \mathrm{~nm})^{\mathrm{c}}\end{array}$ \\
& & $0.0809(229 \mathrm{~nm})$ \\
Duodenal digesta & $0.0489(229 / 470 \mathrm{~nm})$ & $0.1051-0.2853(229 \mathrm{~nm})$ \\
& $0.062-0.2731(229 / 470 \mathrm{~nm})$ & $0.1432-0.3171(340 \mathrm{~nm})$ \\
\hline $\begin{array}{l}\text { Feeds incubated } \\
\text { in the rumen fluid }\end{array}$ & & 0 \\
\hline
\end{tabular}

${ }^{a}$ the wavelengths of an excitation and emission, respectively

${ }^{b}$ the wavelengths of UV monitoring

c the UV detection used in our previous study (Czauderna et al., 1999)

Peak 2 depended upon the detector used and type of processed samples (Table 2). It can be observed from Table 2 that the area ratio of DAPA peaks (i.e. 0.0257) for the processed bacteria sample is in good agreement with the finding reported in our earlier study (Czauderna et al., 1999). Indeed, when UV detection at $340 \mathrm{~nm}$ was applied to the bacteria samples, the area ratio of Peak 1 to Peak 2 was $0.0276 \pm 0.0008$ (mean \pm SD of 4 processed bacterial hydrolysates) (Czauderna et al., 1999).

Previous studies (Hill et al., 1979; Cooper et al., 1984; Krishnamurti et al., 1984) showed that the response of fluorescence detectors depended upon the wavelengths used for the excitation of an effluent and detection of emission. Similarly, monitoring an effluent at various wavelengths influences the response of a UV detector. Therefore, the responses of these detectors, expressed as the measurements of peak areas, are summarized in Table 3 . As expected, excitation at $229 \mathrm{~nm}$ and UV monitoring at the $229 \mathrm{~nm}$ provided greater responses of detectors as compared to excitation and UV detection at $340 \mathrm{~nm}$ (Webster et al., 1990; Czauderna et al., 1999) and the commonly used fluorescence detections (i.e.: an excitation wavelength of $\sim 340 \mathrm{~nm}$, emission cut-off filter of $\sim 425 \mathrm{~nm}$ ) (Puchała et al., 1992; Sarwar et al., 1993; Czauderna et al., 1998). Although the fluorescence emission obtained using $229 \mathrm{~nm}$ produced smaller signals (i.e. peak areas) as compared with UVsignals at $229 \mathrm{~nm}$, fluorescence detection provides better separation of analytical peaks of DAPA from background fluctuations. Moreover, fluorescence detection produced about $<1 / 10$ of the background level of UV detection at $229 \mathrm{~nm}$. Furthermore, the curvilinearity of the UV-background, especially before the first DAPA peak, may seriously affect the accuracy and precision of the integration of the analytical peaks of DAPA. The presented HPLC method with fluorescence detection offers high sensitivity with a limit of detection of $2.05 \mathrm{nmol} / \mathrm{ml}(0.021 \mathrm{nmol} / 10 \mu \mathrm{l}$ injection) and limit of quantification of $6.78 \mathrm{nmol} / \mathrm{ml}(0.068 \mathrm{nmol} / 10 \mu \mathrm{l}$ injection $)$. 
TABLE 3

Effect of detectors setting on the fluorescent and UV signals (i.e. the peak area, $\mathrm{Sn}$ )

\begin{tabular}{|c|c|c|c|}
\hline $\begin{array}{l}\text { Retention } \\
\text { time, } \\
\text { min }\end{array}$ & $\begin{array}{c}\text { Fluorescence detector } \\
\text { response } \\
\mathrm{S}_{n}, \mu \mathrm{V}^{*} \mathrm{sec}\end{array}$ & $\begin{array}{l}\text { Retention } \\
\text { time } \\
\text { min }\end{array}$ & $\begin{array}{l}\text { UV detector } \\
\text { response } \\
S_{n}, \mu V^{*} \sec \end{array}$ \\
\hline & $(229 / 470 \mathrm{~nm})^{\mathrm{a}}$ & & $(229 \mathrm{~nm})^{\mathrm{b}}$ \\
\hline $32.850^{\mathrm{c}}$ & 74559 & $32.783^{c}$ & 48242 \\
\hline $33.842(\text { Peak } 1)^{d}$ & 20517 & 33.758 (Peak 1) $^{\mathrm{d}}$ & 55225 \\
\hline $34.258(\text { Peak } 2)^{d}$ & 98482 & $34.183(\text { Peak } 2)^{\mathrm{d}}$ & 193624 \\
\hline $35.258^{c}$ & 5753563 & $35.167^{\circ}$ & 2771153 \\
\hline \multirow[t]{2}{*}{$\sum^{\text {Total }} \mathrm{S}_{11} \mathrm{e}^{-}$} & 79068361 & $\sum^{\text {Total }} S_{n}^{e}$ & 337022663 \\
\hline & $(340 / 425 \mathrm{~nm})^{\mathrm{a}}$ & & $(340 \mathrm{~nm})^{\mathrm{b}, \mathrm{f}}$ \\
\hline $32.883^{c}$ & 70995 & $32.808^{\mathfrak{c}}$ & 9298 \\
\hline $33.842(\text { Peak } 1)^{d}$ & 9285 & $33.775{(\text { Peak } 1)^{d}}^{d}$ & 9311 \\
\hline $34.267(\text { Peak } 2)^{d}$ & 53534 & $34.200($ Peak 2) & 31604 \\
\hline $35.250^{\circ}$ & 2672974 & $35.175^{\mathrm{c}}$ & 505732 \\
\hline$\sum^{\text {Total }} \mathrm{S}_{\mathrm{n}}^{\mathrm{e}}$ & 38879882 & $\sum^{\text {Total }} S_{n}{ }^{e}$ & 15310203 \\
\hline
\end{tabular}

${ }^{a}$ the wavelengths of an excitation and emission, respectively

b the wavelengths of UV monitoring

" the near unidentified species

d the DAPA peaks

${ }^{c}$ an area of all peaks on a chromatogram

${ }^{\mathrm{r}} \mathrm{UV}$-detection used in our previous study (Czauderna et al., 1999)

Thus, we have demonstrated that the proposed HPLC method in combination with fluorescence detection $(229 / 470 \mathrm{~nm})$ gives better sensitivity than UV detection at $340 \mathrm{~nm}$ (Czauderna et al., 1999).

The response (a peak area, $S_{n}$ ) of DAPA stereoisomers (i.e. as Peaks 1 and Peak 2$)$ or the sum of these stereoisomers (i.e.: $\Sigma\left(S_{n}{ }^{\text {Pcak } 1}+S_{n}{ }^{\text {Peak } 2}\right)$ were linearly related to the amount of DAPA within a wide range of DAPA content (0.19-2.62 $\mu \mathrm{g}$ ) in the processed samples. The correlation coefficients (r) and standard errors in slopes (SES) (Table 4) evidenced that the proposed fluorescence detection offers better linearity of DAPA derivative responses as compared with UV monitoring at $229 \mathrm{~nm}$.

UV detection at $229 \mathrm{~nm}$ can provide a possible alternative DAPA monitoring method. As can be seen from the results summarized in Tables 3 and 4, the proposed method offers a better detector response and linearity of DAPA derivatives (see the values of $\mathrm{r}$ and SES) as compared with the UV detection used in our previous study (Czauderna et al., 1999). 
TABLE 4

Linear regression of DAPA-OPA derivative standards, the coefficients correlation ( $\mathrm{r}$ ) and standard error in slope (SES)

\begin{tabular}{|c|c|c|c|}
\hline $\begin{array}{l}\text { DAPA } \\
\text { peaks }\end{array}$ & Equations" & $\begin{array}{l}\text { Correlation } \\
\text { coefficient, } \mathrm{r}\end{array}$ & $\begin{array}{l}\text { Standard error } \\
\text { in slope, SES }\end{array}$ \\
\hline \multicolumn{4}{|c|}{$\begin{array}{l}\text { Fluorescence detection } \\
\text { (an excitation wavelength of } 229 \mathrm{~nm} \text {, emission cut-off filter of } 470 \mathrm{~nm} \text { ) }\end{array}$} \\
\hline Peak 1 & $y=6.649 \times 10^{-6} S_{n}-0.025$ & 0.99976 & $7.281 \times 10^{-8}$ \\
\hline Peak 2 & $y=5.168 \times 10^{-6} S_{n v}-0.024$ & 0.99986 & $4.409 \times 10^{-8}$ \\
\hline & $y=2.908 \times 10^{-5} S_{n}-0.024$ & & \\
\hline The $\operatorname{sum}^{b}$ & $\mathrm{y}=5.953 \times 10^{-14} \mathrm{~S}_{\mathrm{n}}^{2}+2.854 \times 10^{-6} \mathrm{~S}_{\mathrm{n}}-0.019$ & 0.99982 & $2.758 \times 10^{-8}$ \\
\hline \multicolumn{4}{|c|}{ (UV detection monitoring at $229 \mathrm{~nm}$ with an attenuation of 0.01 a.u.f.s.) } \\
\hline Peak 1 & $y=3.328 \times 10^{-6} S_{n}-0.043$ & 0.99844 & $1.073 \times 10^{-7}$ \\
\hline Peak 2 & $\begin{array}{l}y=2.932 \times 10^{-6} S_{n}^{n}-0.051 \\
y=1.559 \times 10^{-6} S_{n}-0.047\end{array}$ & 0.99820 & $1.015 \times 10^{-7}$ \\
\hline The sumb & $y=6.021 \times 10^{-14} S_{n}^{2}+1.456 \times 10^{-6} S_{n}-0.026$ & 0.99833 & $0.520 \times 10^{-7}$ \\
\hline
\end{tabular}

a $S_{n}$ and $y$ are the peak area and the DAPA content $(\mu \mathrm{g})$ in processed samples $(v=430 \mu \mathrm{l})$. Injection volumes were $20 \mu 1$

${ }^{b}$ the equations were calculated from the sum of both DAPA peaks (i.e.: Peaks 1 and 2)

\section{Reliability of HPLC method}

System reproducibility and reliability of the proposed HPLC method were evaluated by analyzing the within and between run coefficients of variation (C.V., \%) calculated from the quantification of DAPA in biological or standard samples. The results obtained from chromatographic runs summarized in Table 5 show that the use of fluorescence detection and the sum of DAPA peaks gives the DAPA analysis method better precision.

Recoveries of DAPA standards from feed hydrolizates obtained by incubation in rumen fluid are presented in Table 6. Accuracy of the HPLC separation was assessed using fluorescence or UV detection based on Peak 1 and Peak 2. It can be seen that the accuracy of the method is better when the DAPA measurements were based on the larger DAPA peak. As expected, the use of fluorescence detection and the sum of DAPA peaks gave the best accuracy of the new HPLC procedure. Attempts were also made to compare the results of DAPA quantification of the presented method with the results of our earlier method (Czauderna et al., 1999). As expected, both methods provide excellent agreement. In fact, the DAPA content in the bacteria sample determined by the new method was $0.638 \%$ 
TABLE 5

The within and between run coefficients (C.V., \%) derived from quantification of DAPA in biological and standard samples

\begin{tabular}{lll}
\hline & \multicolumn{3}{l}{ Precision, $\%$} \\
\cline { 2 - 3 } Used DAPA peak & C.V. within run $^{\mathrm{a}}$ & C.V. between run \\
\hline
\end{tabular}

Fluorescence detection

(an excitation wavelength of $229 \mathrm{~nm}$, emission cut-off filter of $470 \mathrm{~nm}$ )

$\begin{array}{llll}\text { Peak 1 } & 0.045 \pm 0.034 & 0.043 \pm 0.016 & 0.175 \pm 0.147 \\ \text { Peak 2 } & 0.027 \pm 0.021 & 0.033 \pm 0.017 & 0.046 \pm 0.037 \\ \sum \text { (Peak 1 and 2) } & 0.026 \pm 0.018 & 0.033 \pm 0.016 & 0.035 \pm 0.026\end{array}$

UV detection

(monitoring at $229 \mathrm{~nm}$ with an attenuation of 0.01 a.u.f.s.)

$\begin{array}{llll}\text { Peak 1 } & 0.030 \pm 0.013 & 0.029 \pm 0.013 & 0.134 \pm 0.089 \\ \text { Peak 2 } & 0.025 \pm 0.019 & 0.047 \pm 0.021 & 0.044 \pm 0.029 \\ \Sigma\left(\text { Peak 1 and 2) }{ }^{d}\right. & 0.019 \pm 0.013 & 0.035 \pm 0.012 & 0.050 \pm 0.023\end{array}$

a the within run C.V. based on 4 samples each with $3-5$ injections (samples stored at $-28^{\circ} \mathrm{C}$ )

${ }^{b}$ the between run C.V. based on 4 samples each repeated 2-4 times (derivatization and injection)

' the total between run C.V. based on 7 in vitro incubated biological samples each repeated two times (hydrolysis, derivatization and injection)

d the sum of DAPA peaks (i.e.: Peaks 1 and 2)

(fluorescence detection: $229 / 470 \mathrm{~nm}$ ) or $0.650 \%$ (UV detection at $229 \mathrm{~nm}$ ), while the DAPA level in the same sample processed by our earlier method was $0.631 \%$ (Czauderna et al., 1999). Similarly, good results were obtained for duodenal digesta: the DAPA content analyzed by the new method was $0.070 \%$ (fluorescence detection: $229 / 470 \mathrm{~nm}$ ) or $0.069 \%$ (UV detection at $229 \mathrm{~nm}$ ), while the DAPA concentration by our earlier method was $0.072 \%$.

The OPA derivatization procedure has become popular because the fluorescent products have a high quantum yield and the reagent itself does not fluoresce. However, the relative instability of the formed derivatives, as the result of intermolecular rearrangement (Simon et al., 1976), affects the accuracy, precision and reproducibility of the presented method. Therefore, the stability of the derivatization adducts was investigated and the derivatization reaction was optimized with respect to reaction time and temperature (derivatized samples were protected from the light). It seems clear from the results in Table 7 that the DAPA-OPA derivatives were stable for at least $52 \mathrm{~min}$ at $6^{\circ} \mathrm{C}$. Moreover, our studies indicate that only fluorescence detection resulted in satisfactory resolution of DAPA from fluorescent impurities or background-fluctuation interference. Indeed, HPLC analysis of biological samples with fluorescence detection showed that the number of small peaks near the DAPA peaks increased. As expected, a rise in temperature caused more 
TABLE 6

Results of recoveries ( $\mathrm{R}, \%)$ of DAPA added to biological samples

\begin{tabular}{|c|c|c|c|c|}
\hline \multirow{2}{*}{$\begin{array}{l}\text { DAPA } \\
\text { added, } \mu \mathrm{g}\end{array}$} & & & \multicolumn{2}{|c|}{ Recovery, R, \% a } \\
\hline & & & fluorescence detection ${ }^{b}$ & UV detection $^{c}$ \\
\hline & & Peak 1 & $96.9 \pm 4.5$ & $92.9 \pm 4.5$ \\
\hline \multirow[t]{2}{*}{0.262} & & Peak 2 & $102.2 \pm 4.0$ & $98.1 \pm 4.6$ \\
\hline & & $\sum(\text { Peak } 1 \text { and } 2)^{d}$ & $99.9 \pm 4.1$ & $95.6 \pm 4.9$ \\
\hline & & Peak 1 & $98.9 \pm 1.5$ & $95.7 \pm 2.0$ \\
\hline \multirow[t]{2}{*}{0.523} & & Peak 2 & $99.2 \pm 2.9$ & $97.7 \pm 3.2$ \\
\hline & & $\Sigma($ Peak 1 and 2$)$ & labes:- & $95.3 \pm 2.3$ \\
\hline & & Peak 1 & $104.4 \pm 3.2$ & $100.1 \pm 10.4$ \\
\hline \multirow[t]{2}{*}{0.697} & & Peak 2 & $102.5 \pm 1.7$ & $99.8 \pm 8.0$ \\
\hline & & $\sum($ Peak 1 and 2$)$ & $104.2 \pm 1.8$ & $99.9 \pm 9.2$ \\
\hline \multirow{3}{*}{1.093} & & Peak 1 & $97.3 \pm 3.0$ & $95.1 \pm 5.1$ \\
\hline & & Peak 2 & $98.0 \pm 1.0$ & $100.8 \pm 6.7$ \\
\hline & & $\Sigma($ Peak 1 and 2$)$ & $97.4 \pm 1.8$ & $97.3 \pm 4.7$ \\
\hline \multirow{3}{*}{2.093} & & Peak 1 & $97.6 \pm 2.4$ & $96.1 \pm 1.9$ \\
\hline & & Peak 2 & $98.2 \pm 2.1$ & $98.0 \pm 1.4$ \\
\hline & & $\sum($ Peak 1 and 2$)$ & $97.8 \pm 2.1$ & $97.0 \pm 1.2$ \\
\hline Pooled & & Peak 1 & $98.0 \pm 3.4$ & $95.3 \pm 4.4$ \\
\hline \multirow[t]{2}{*}{ Data } & & Peak 2 & $99.4 \pm 2.9$ & $98.9 \pm 4.7$ \\
\hline & & $\Sigma($ Peak 1 and 2$)$ & $98.4 \pm 3.1(n=30)^{e}$ & $96.7 \pm 4.0(n=27)^{c}$ \\
\hline
\end{tabular}

a recovery was calculated as: $\mathrm{R}(\%)=\left(\mathrm{S}_{1}-\mathrm{S}_{0}\right) \times 100 / \mathrm{A}$, where $\mathrm{S}_{1}$ and $\mathrm{S}_{0}$ are measurements of DAPA peak area (i.e.: Peak 1 or/and 2) before and after addition of DAPA standard to biological samples, and $\mathrm{A}$ is the amount of DAPA added

b the fluorescence detection at an excitation wavelength of $229 \mathrm{~nm}$ and emission cut-off filter of 470 $\mathrm{nm}$

c the UV monitoring of the effluent at $229 \mathrm{~nm}$ with an attenuation of 0.01 a.u.f.s.

${ }^{d}$ the determination of recoveries was based on the sum of DAPA peaks (i.e.: Peaks 1 and 2)

e number of replicates

rapid decomposition of DAPA derivatives. The results showed that a decreasing amount of DAPA derivatives can be observed after $52 \mathrm{~min}$ at $20^{\circ} \mathrm{C}$. Obviously, only fluorescence detection is an adequate tool for the quantification of DAPA at both $6^{\circ} \mathrm{C}$ and $20^{\circ} \mathrm{C}$.

Considering the above results and our earlier studies (Czauderna et al., 1999), it can be concluded that in order to obtain good reproducibility, the reaction time should be fixed at 3 to $6 \mathrm{~min}$ at room temperature. 
TABLE 7

Effect of time and temperature on the stability of DAPA derivatives ${ }^{a}$ in two different biological samples

\begin{tabular}{|c|c|c|c|c|c|}
\hline & \multirow[b]{2}{*}{ Time, $\min$} & \multicolumn{2}{|c|}{ Fluorescence detection $^{b}$} & \multicolumn{2}{|c|}{ UV detection ${ }^{c}$} \\
\hline & & $6^{\circ} \mathrm{C}$ & $20^{\circ} \mathrm{C}$ & $6^{\circ} \mathrm{C}$ & $20^{\circ} \mathrm{C}$ \\
\hline \multirow{4}{*}{0} & Peak 1 & 33412 & 21264 & 95999 & 51813 \\
\hline & Peak 2 & 122360 & 82200 & 224825 & 141056 \\
\hline & $\sum(\text { Peak } 1 \text { and } 2)^{d}$ & 155772 & 103464 & 320824 & 192869 \\
\hline & $\sum$ Totals $_{n}{ }^{\circ}$ & 195369201 & 84360235 & 476280107 & 396745917 \\
\hline \multirow{4}{*}{52} & Peak 1 & 33961 & 11306 & 75397 & 45412 \\
\hline & Peak 2 & 119735 & 68876 & 268601 & 155250 \\
\hline & $\sum($ Peak 1 and 2$)$ & 153696 & 80182 & 343998 & 200662 \\
\hline & $\sum$ Totals $_{n} e^{e}$ & 108339001 & 90900638 & 43858417 & 423772451 \\
\hline \multirow{4}{*}{103} & Peak 1 & 27768 & 11467 & 67747 & 45063 \\
\hline & Peak 2 & 115580 & 64689 & 259097 & 155044 \\
\hline & $\Sigma($ Peak 1 and 2$)$ & 143348 & 76156 & 326844 & 200107 \\
\hline & $\sum$ Totals $_{\mathrm{n}}^{\mathrm{e}}$ & 114942335 & 92946226 & 444611077 & 423229561 \\
\hline \multirow{4}{*}{160} & Peak 1 & 24973 & 12395 & 69648 & 53228 \\
\hline & Peak 2 & 115442 & 56323 & 280846 & 142390 \\
\hline & $\Sigma($ Peak 1 and 2$)$ & 140415 & 68718 & 350494 & 195618 \\
\hline & $\sum$ TotalS $_{n}{ }^{c}$ & 117912719 & 97563977 & 456123300 & 427038340 \\
\hline
\end{tabular}

a the reaction time $-4 \mathrm{~min}$ (at room temperature)

b the fluorescence detection at an excitation wavelength of $229 \mathrm{~nm}$ and emission cut-off filter of $470 \mathrm{~nm}$

c the UV monitoring of the effluent at $229 \mathrm{~nm}$ with an attenuation of 0.01 a.u.f.s.

d the sum of DAPA peaks (i.e.: Peaks 1 and 2)

e an area of all peaks on a chromatogram

\section{CONCLUSIONS}

The HPLC method proposed in this study enabled simple and inexpensive quantification of DAPA in rumen bacteria, duodenal digesta and feeds incubated in vitro in rumen fluid. Elimination of the post-column reactor yields a less expensive, more versatile system where rapid analysis and high sensitivity, accuracy and precision can be achieved. The use of only high-efficiency reversed-phase columns assures high selectivity, satisfactory resolution and minimum band broadening. Due to the complete separation of DAPA derivatives and the use of a widely available C-18 columns, the presented HPLC technique has an advantage over classical two-column amino acid analyzers. 
The DAPA derivatives appeared in the chromatograms as two peaks (i.e. partly separated stereoisomers). The use of fluorescence detection and the sum of both DAPA peaks gave the best precision and accuracy of the new HPLC method. Moreover, the $229 \mathrm{~nm}$ excitation wavelength was used to gain greater sensitivity. Obviously, UV detection at $229 \mathrm{~nm}$ can be a possible alternative method for assaying DAPA in biological materials.

Application of gradient elution in conjunction with computer data handling gives high reproducibility of the analyses, rendering the reversed-phase HPLC method suitable for routine analysis of a large number of biological samples.

\section{REFERENCES}

Benson J. R., 1975. R. N. Perham (Editor). Instrumentation in Amino Acid Sequence Analysis. Academic Press, New York, pp. 1-39

Cooper J. D. H., Ogden G., Mc Intosh J., Turnell D. C., 1984. The stability of the $o$-phthalaldehyde/ 2-mercaptoethanol derivatives of amino acids: an investigation using high-pressure liquid chromatography with a precolumn derivatization techniqur. Anal. Biochem. 142, 98-102

Czauderna M., Kowalczyk J., 1998. Determination of free amino acids in blood plasma by highperformance liquid chromatography with fluorescence detection. J. Anim. Feed Sci. 7, 453-463

Czauderna M., Kowalczyk J. Kwiatkowska E., 1999. Measurement of 2,6-diaminopimelic acid in rumen bacteria by various high-performance liquid chromatography methods with pre-column derivatization. Chem. Anal. 44, 243-256

Czerkawski J. W., 1974. Methods for determining 2,6-diaminopimelic acid and 2-aminoethyl-phosphonic acid in gut contents. J. Sci. Food Agric. 25, 45-55

Edols R. W., 1985. Simple method for determination of 2,6-diaminopimelic acid and 2-amino-ethylphosphonic acid in gut contents. J. Sci. Food Agric. 25, 45-55

El-Shazly K., Hungate R. E., 1966. Method for measuring diaminopimelic acid in total rumen contents and its application to the estimation of bacterial growth. Appl. Microbiol. 14, 27-30

El-Waziry A. M., Tomita Y., Ling J. R., Onodera R., 1996. Measurement of total and separate stereoisomers of diaminopimelic acid in rumen bacteria by high-performance liquid chromatography. J. Chromatogr. B 677, 53-59

Gratzfeld-Husgen A., Schuster R., 1994. HPLC for Environmental Analysis. Hewlett-Packard Company, France

Hill D. W., Walters F. H., Wilson T. D., Stuart J. D., 1979. High performance liquid chromatographic determination of amino acids in the picomole range. Anal. Chem. 51, 1338-1341

Hoshino S., Onodera R., Minato H., Itabashi H., 1990. The rumen ecosystem - The microbial metabolism and its regulation. Japan Sci. Soc. Press, Tokyo, pp. 83

Krishnamurti C. R., Heindze A. M., Galzy G., 1984. Application of reversed-phase high-performance liquid chromatography using pre-column derivatization with $o$-phthaldaldehyde for the quantitative analysis of amino acids in adult and fetal sheep plasma, animal feeds and tissues. J. Chromatogr. 315, 321-331

Masson H. A., Denholm A. M., Ling J. R., 1991. In vivo metabolism of 2,6-diaminopimelic acid from gram-positive and gram-negative bacterial cells by ruminal micro-organisms and ruminants and its use as a marker of bacterial biomass. Appl. Environ. Microbiol. 56, 1714-1720 
Mohau S., Dow C., Cole J. A., 1992. Prokaryotic Structure and Function: A new Perspective. Cambridge University Press, Cambridge, pp. 185

Nagasawa T., Ling J. R., Onodera R., 1993. Chiral high-performance liquid chromatographic separation of the stereoisomers of 2,6-diaminopimelic acid without derivatization. J. Chromatogr. A $653,336-340$

Puchała R., Piór H., Kulasek G. W., Shelford J. A., 1992. Determination of diaminopimelic acid in biological materials using high-performance liquid chromatography. J. Chromatogr. 623, 63-67

Rattenbury J.M., 1981. Amino Acids Analysis. John Wiley and Sons, New York, pp. 37-47 and 6670

Robinson P. H., Fadel J. G., Ivan M., 1996. Critical evaluation of diaminopimelic acid and ribonucleic acid as markers to estimate rumen pools and duodenal flows of bacterial and protozoal nitrogen. Can. J. Anim. Sci. 76, 587-597

Roth M., 1971. Fluorescence reaction for amino acids. Anal. Chem. 43, 880-882

Sarwar G., Botting H. G., 1993. Evaluation of liquid chromatographic analysis of nutritionally important amino acids in food and physiological samples. J. Chromatogr. 615, 1-22

Simons S. S., Johnson D. V., 1976. The structure of the fluorescent adduct formed in the reaction of $o$-phthaldialdehyde and thiols with amines. J. Amer. Chem. 98, 7098

Webster P. M., Hoover W. H., Miller T. K., 1990. Determination of 2,6-diaminopimelic acid in biological materials using high performance liquid chromatography. Anim. Feed Sci. Technol. 30, $11-20$

\section{STRESZCZENIE}

Oznaczanie kwasu 2,6-dwuaminopimelinowego w masie bakteryjnej, treści żwacza i dwunastnicy metodą HPLC z detektorem UV lub fluorescencyjnym

Kwas 2,6-dwuaminopimelinowy (DAPA) oznaczano w próbach masy bakteryjnej żwacza oraz w treści żwacza i dwunastnicy owiec, stosując aparaturę HPLC z detektorem UV lub fluorescencyjnym, po ich hydrolizie w $6 \mathrm{M} \mathrm{HCl}$ przez 20 godzin w temperaturze $104 \pm 2{ }^{\circ} \mathrm{C}$. Po odparowaniu hydrolizatu DAPA przeprowadzano w związek pochodny używając $o$-dialdehyd ftalowy w obecności etanotiolu. Pochodne stereoizomerów DAPA rozdziclano na kolumnie C- $18 \mathrm{z}$ odwróconą faza (Nova-Pak, $4 \mu \mathrm{m}, 250 \times 4,6 \mathrm{~mm}$ ) poprzez elucje gradientową. Wszystkie pochodne oznaczano stosując detekcję fluorescencyjną (wzbudzenie $229 \mathrm{~nm}$, pomiar $470 \mathrm{~nm}$ ) lub monitorowanie UV przy $229 \mathrm{~nm}$. Czas rozdziału stereoizomerów DAPA w dwóch pikach uzyskano po 35 minutach elucji gradientowej. Średni odzysk standardów DAPA dodanych do analizowanych próbek wynosił $98,4 \pm 3,1 \%$ przy detekcji fluorescencyjnej i $96,7 \pm 4,0 \%$ przy detekcji UV. Niskie wartości współczynnika zmienności w obrębie przeprowadzania w pochodne i iniekcji prób, szybkość analizy oraz wysoka czulość na poziomie nmoli sprawiaja, że metoda może być stosowana z powodzeniem do oznaczenia DAPA w materiale biologicznym. 